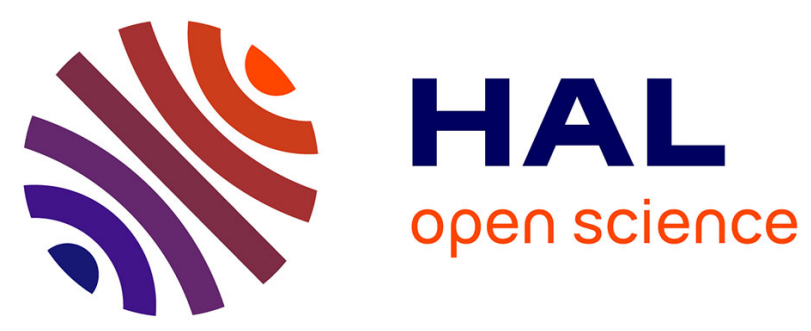

\title{
Erosion modeling and tracing sediment sources at Guarda Mor catchment in southern Brazil
}

Alice Dambroz, Jean Minella, Tales Tiecher, Jean Moura-Bueno, Felipe Bernardi, Fabio Schneider, Olivier Evrard

\section{To cite this version:}

Alice Dambroz, Jean Minella, Tales Tiecher, Jean Moura-Bueno, Felipe Bernardi, et al.. Erosion modeling and tracing sediment sources at Guarda Mor catchment in southern Brazil. EGU General Assembly 2021, 19-30 April 2021, Apr 2021, Vienne, Austria. 10.5194/egusphere-egu21-12917 . cea03168663

\section{HAL Id: cea-03168663 https://hal-cea.archives-ouvertes.fr/cea-03168663}

Submitted on 14 Mar 2021

HAL is a multi-disciplinary open access archive for the deposit and dissemination of scientific research documents, whether they are published or not. The documents may come from teaching and research institutions in France or abroad, or from public or private research centers.
L'archive ouverte pluridisciplinaire HAL, est destinée au dépôt et à la diffusion de documents scientifiques de niveau recherche, publiés ou non, émanant des établissements d'enseignement et de recherche français ou étrangers, des laboratoires publics ou privés. 
EGU21-12917

https://doi.org/10.5194/egusphere-egu21-12917

EGU General Assembly 2021

(c) Author(s) 2021. This work is distributed under

the Creative Commons Attribution 4.0 License.

\title{
Erosion modeling and tracing sediment sources at Guarda Mor catchment in southern Brazil
}

\author{
Alice Dambroz ${ }^{1}$, Jean Minella ${ }^{1}$, Tales Tiecher ${ }^{2}$, Jean Moura-Bueno ${ }^{1}$, Felipe Bernardi ${ }^{1}$, Fabio \\ Schneider ${ }^{1}$, and Olivier Evrard ${ }^{3}$ \\ ${ }^{1}$ Soil Science Department, Universidade Federal de Santa Maria (UFSM), Santa Maria, Brazil (alice_pbd@outlook.com) \\ ${ }^{2}$ Soil Science Department, Universidade Federal do Rio Grande do Sul (UFRGS), Porto Alegre, Brazil \\ ${ }^{3}$ Laboratoire des Sciences et de l'Environnement (LSCE - IPSL), Unité Mixte de Recherche 8212 (CEA/CNRS/UVSQ), Université \\ Paris-Saclay, Gif-sur-Yvette, France
}

Although sediment yield reflects a catchment's erosive processes, material transfer from hillslopes to rivers depends on a series of phenomena occurring on variable and continuous range of scales. Physically based, distributed models can be used to evaluate erosion's spatial variability within a catchment and to identify hotspots. Sediment fingerprinting allows source type discrimination based on sediment and soil properties. The analysis of these dynamic systems could be coupled by addressing hillslope processes with modeling, while fingerprinting enlightens the connection between them and the drainage network. We aimed to evaluate the erosive susceptibility and its spatial distribution in three environmentally fragile paired headwater catchments, nested within Guarda Mor catchment, located in the border of the volcanic plateau in southern Brazil. This catchment is characterized by intense agricultural use, diverse geology, and complex terrain. WATERSED model was used as a dynamic method to evaluate the spatial distribution of hydrologic and erosive fragility during rainfall events. WATERSED was parameterized for modeling surface runoff volume, sediment yield and interrill erosion, based on monitored data from a zero-order notill catchment and literature data. Modeling results were analyzed for each land use. For fingerprinting, two sediment sampling strategies and source groupings were considered. One considered spatial sources, and the endmembers were the sub catchments, the other considered land use source types within each sub catchment. Deposited bed sediment samples were collected at the outlets of each sub catchment and the main outlet. Soil source samples were collected in crop fields, grasslands, stream channels, forests, and unpaved roads. Crop fields and grasslands compose the source type topsoil. Samples were analyzed by near-infrared spectroscopy. Artificial mixtures were made to calibrate the prediction models. Fifteen Support Vector Machine (SVM) models were built and independently trained. Modeled erosion indicates that the steepest areas and those near the drainage network can be the most susceptible to erosion and runoff. The spatial distribution of runoff-prone areas shows the connectivity from upper segments of these catchments increases with higher magnitude events. In fingerprinting, calibration results' predictors show good performance by the models, validation results vary from poor to good. SVM models for unpaved roads and forest had the best validation performance. For sourcing tributaries, results and poor validation statistical results indicate the need to use different 
tracers, and to consider unsampled sources associated to soil and geological differences found downstream from the sub catchment's outlets. As for the sub catchments, there is a variation among the main sediment sources and a significantly constant contribution from unpaved roads in all of them. Other important sources are topsoil and stream channels, while forests did not show significant contribution. These methodologies were useful in seeking a more holistic process understanding, as physical processes were addressed and later integrated with the resulting sediment yield. Despite the results are modelled, the complementation of their insights indicates that there is a possibility for validating the sediment fingerprinting technique once modelling is validated by monitored and measured data. 